\title{
Permainan Ular Tangga Berbasis Arduino UNO dan RFID Guna Mengembangkan IImu Pengetahuan Anak Sekolah Dasar dalam Mengenal Jenis Tanaman
}

\author{
Deny Nusyirwan (1), Aldo Guntara (2), Prasetya Perwira Putra Perdana ${ }^{(3)}$ \\ $(1,2,3)$ Teknik Elektro, Universitas Maritim Raja Ali Haji \\ (1) denynusyirwan@umrah.ac.id \\ DOI: https://doi.org/10.21107/rekayasa.v13i1.5414
}

\begin{abstract}
ABSTRAK
Anak sekolah dasar kurang ingin memainkan sebuah permaianan yang menurutnya membosankan dan tertuju pada pemikiran yang menguras fikiran mereka, sebagai contohnya yaitu permainan hitung dan soal jawaban sebagai simulasi kecerdasan mereka, namun dari solusi tersebut ketertarikan mereka menurun, disebabkan karena belum adanya jawaban dari permasalahan yang membuat mereka tertarik akan permainan ilmu pengetahuan. Pada penelitian yang dilakukan oleh Samuel Gandang Gunanto seorang Mahasiswa Institut Seni Indonesia Yogyakarta, yang di terbitkan oleh Journal of animation and games studies pada Oktober 2016. Penciptaan karya ini dikembangkan segi imersif dari sebuah game yang nyata. Pembelajaran pendidikan karakter, secara khusus tentang sikap kepedulian terhadap kebersihan lingkungan. Dengan inovasi sebelumna, maka dapat dibandingkan dengan inovasi permaianan ular tangga, yang dikembangkan melalui permaianan manual berbasis digital. Cara kerjanya menggunakan RFID sebagai sarana pendeteksi jawaban jenis tanaman yang akan meningkatkan ilmu pengetahuan tentang tanaman. Penelitian dimulai dengan pendekatan Double Diamand yang diperkenalkan oleh British Design Council, yaitu memulai proses perancangan dengan social research yang di integrasikan dengan design thinking untuk dapat menghasilkan inovasi berbasis teknologi yang bermanfaat bagi masyarakat setempat. Setelah mendapatkan solusi utama, maka akan dilanjutkan dengan pembuatan sederhana yang akan dipergunakan untuk uji fungsi dan manfaat bersama calon pengguna.
\end{abstract}

Kata Kunci: sekolah, permainan, tanaman, Arduino, RFID

\section{Snakes and Ladders Game based on Arduino UNO and RFID to Develop The Knowledge of Elementary School Students in Recognizing The Type of Plants}

\section{ABSTRACT}

Elementary school children don't want to play a game that they think is boring and fixed on thoughts that drain their minds, for example counting games and answer questions as a simulation of their intelligence, but from these solutions their interest decreases, because there are no answers to the problems that make they are interested in the game of science. The research was conducted by Samuel Gandang Gunanto, a student at the Indonesian Institute of the Arts in Yogyakarta, published by the Journal of animation and games studies in October 2016. The creation of this work was developed in terms of immersiveness of a real game. Character education learning, specifically about caring about environmental cleanliness. With previous innovations, it can be compared to the snake ladder game innovation, which was developed through a digital-based manual game. The way it works uses RFID as a means of detecting answers to plant types that will improve knowledge about plants. The research began with the Double Diamand approach introduced by the British Design Council, which began the design process with social research which was integrated with design thinking to be able to produce technology-based innovations that benefit the local community. After getting the main solution, it will be followed by a simple manufacture that will be used to test the functions and benefits with prospective users.

Keywords: school, games, plants, Arduino, RFID

\section{PENDAHULUAN}

Perkembangan industri game saat ini sangat meningkatkan peran ilmu pengetahuan, salah satu sasarannya adalah anak sekolah dasar. Sebagaimana jenis game berusaha untuk mensimulasikan kehidupan sehari-hari secara nyata dan dapat mengasah karakter anak dalam ilmu pengetahuan. Sebagai contoh adalah permainan yang berkaitan tentang suatu objek yang menjadi sasaran pengetahuan untuk membentuk karakter anak menjadi lebih baik dalam bidang bakatnya. Permainan ta-

\section{Article History:}

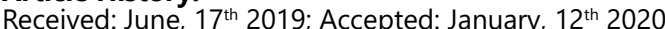

ISSN: 2502-5325 (Online) Terakreditasi Peringkat 3 oleh Kementerian Riset, Teknologi dan Pendidikan Tinggi (ARJUNA), berdasarkan Keputusan Direktur Jenderal Penguatan Riset dan Pengembangan No: 23/E/KPT/2019 tanggal 8 Agustus 2019 naman menjadi salah satu permainan ya ng membentuk karakter anak dalam mengenal lingkungan hidup, peduli dengan keadaan sekitar dan menjadikan lingkungan sebagian dari kehidupan mereka. Sebagai contohnya yaitu menciptakan sebuah inovasi teknologi yang berkaitan dengan jenis tanaman sebagai objek ilmu pengetahuan yang menjadi peran penting dalam membentuk karakter terkhusus anak sekolah dasar.

\section{Cite this as:}

Nusyirwan, D. Guntara, A. \& Perdana, P.P.P. (2020). Permainan Ular Tangga Berbasis Arduino Uno dan RFID Guna Mengembangkan Ilmu Pengetahuan Anak Sekolah Dasar dalam Mengenal Jenis Tanaman. Rekayasa, 13(1), 88-96. doi: https://doi. org/10.21107/rekayasa.v13i1.5414 
Inovasi ini berupaya dalam membentuk pola fikir anak usia dini, maka diciptakannya solusi sebagai pemecahan permasalahan yang terjadi pada era digital. Saat ini anak sekolah dasar kurang ingin memainkan sebuah permaianan yang menurutnya membosankan dan tertuju pada pemikiran yang menguras fikiran mereka, sebagai contohnya yaitu permainan hitung dan soal jawaban sebagai simulasi kecerdasan mereka, namun dari solusi tersebut ketertarikan mereka menurun, ini disebabkan karena belum adanya jawaban dari permasalahan yang membuat mereka tertarik akan permainan yang masih mencakup ilmu pengetahuan.

Selanjutnya diciptakannya sebuah solusi efektif yaitu inovasi permaianan ular tangga, yang dikembangkan melalui permaianan manual berbasis digital. Menggunakan RFID sebagai sarana pendeteksi jawaban jenis tanaman yang akan meningkatkan ilmu pengetahuan tentang tanaman, dari permaianan ini akan menghasilkan efektifitas peningkatan ilmu pengetahuan anak sekolah dasar tentang pentingnya mengenal jenis tanaman dan lingkungan hidup sebagai keberlangsungan

\section{KAJIAN PUSTAKA}

Didalam penelelitian ini, telah di lakukan kajian terhadap penelitian terdahulu yang akan di pergunakan sebagai batasan terhadap penelitian yang akan di lakukan, selain itu kajian pustaka juga akan menjelaskan mengenai cara kerja purwarupa dan komponen yang diperlukan.

\section{Penelitian terdahulu}

Global warming adalah pemanasan global yang berdasarkan isu karena adanya proses peningkatan suhu. Global Warming yaitu konsep Go Green yang melibatkan masyarakat dan anak-anak untuk berpartisipasi. Penelitian yang dilakukan oleh Evelina Wijaya yang diterbitkan pada tahun 2013 oleh calyptra dengan judul Perancangan permainan greenplay sebagai sarana pembelajaran peduli lingkungan bagi anak-anak, mengenalkan material ramah lingkungan dan pemanfaatanya dalam produk sejak dini pada anak-anak, permainan Green Play adalah permainan yang memiliki tanggung jawab dan lingkungan sosial, konsep yang dipakai learn and play penelitian ini muatan permainan go green yang dapat membantu anak bermain serta belajar peduli lingkungan, yang diberi nama kideko (Wijaya, 2013).

Perancangan Board game edukatif tentang peduli lingkungan untuk anak usia 7-12 tahun, penelitian ini dilakukan oleh Dede Jordi pada tahun 2017 yang merupakan Mahasiswa Universitas Negeri Padang yang menerapkan permainan edukatif Board Game memperkenalkan subjek pada target audiance yaitu packing, rulebook, kalender, gantungan kunci, pin, jam dinding, dan stiker, metode pendekatan ini melalui $5 \mathrm{~W}+1 \mathrm{H}$ yang dijadikan konsep pemecahan masalah. Tujuannya adalah memberikan gambaran hasil analisis sehingga permainan ini menjadi yang efektif dan komunikatif (Jordi, 2013).

The games 3-6 aged children's wish to play in the school garden adalah sebuah yang dilakukan oleh Mage Yurtseuer Kilicaun, penelitian ini dilakukan pada tahun 2014 yang diterbitkam oleh Elsevier Ltd. Tujuan penelitian ini adalah untuk menentukan apa yang anak-anak usia 3-6 tahun lakukan di taman sekolah, untuk bermain ditaman sekolah dianalisis dibawah 3 judul jenis kegiatan, struktur, dan jumlah pemain. Terdapat 139 anak perempuan, 145 anak laki-laki, total 284 anak diambil contoh. Terdapat 63 anak berumur 3 tahun, 77 anak berumur 4 tahun, 82 anak berumur 5 tahun, dan 62 anak berumur 6 tahun. Dalam ulasan ini diminta anak usia 3-6 tahun membayangkan permainan apa yang akan di mainakan di taman lalu digambarkan (Kilicaun, 2014) [3].

Penciptaan Permainan Digital Edukatif Berbasis Wawasan Budaya dan Pendidikan Karakter. Pada penelitian yang dilakukan oleh Samuel Gandang Gunanto seorang Mahasiswa Institut Seni Indonesia Yogyakarta, yang di terbitkan oleh Journal of animation and games studies pada Oktober 2016. Penciptaan karya ini dikembangkan segi imersif dari sebuah game yang nyata. Pembelajaran pendidikan karakter, secara khusus tentang sikap kepedulian terhadap kebersihan lingkungan. Tema pendidikan karakter dalam wujud karya game sangat menarik untuk diangkat dan penanaman kepedulian terasa lebih mengena digambarkan dalam bentuk partisipasi dalam tingkah laku (Gunanto, 2016)

Perkembangan model game theory pada skema persedian penyangga untuk menjamin ketersediaan dan kestabilan harga komoditas gula pasir. Penelitian yang dilakukan oleh Mahesa Janar, Wahyudi Sutopo, Yurianistanto, seorang Mahasiswa Universitas Sebelas Maret dari jurusan teknik Industri Fakultas teknik. Dalam penelitian ini digunakan game theory untuk menganalisis dalam pengambilan keputusan dari kepentingan yang terkait. Game Theory dapat merefleksikan beberapa melalui strategi yang dikembangkan (Janar, Sutopo, and Yurianistanto, 2015)

\section{Landasan Teori}

Permaianan ular tangga diterapkan melalui aturan main, yaitu lempar dadu dan maju sebagai pemenang. Setiap dadu dilemparkan maka permainan ini dapat dilanjutkan dengan menggeser tanda main atau jagoan yang akan di majukan dalam permainan ini. Jika jagoan tersebut menemukan sebuah tangga untuk naik, maka permainan akan dihentikan sejenak untuk memilih sebuah kartu, karena sistem dari permainan ini ingin mengasah kemampuan untuk melalui tahap-tahap sulit sebagai pembentukan pola fikir anak.

Untuk dapat menjadi sang juara, maka anak sekolah dasar akan diwajibkan untuk membaca buku 
panduan terlebih dahulu, sebagai teori dasar dalam permaianan ini. Dikasi waktu 5 menit untuk memahami tata cara main dan potensi ikan yang sudah disediakan di buku panduan. Dengan begitu, permainan akan segera dapat dimulai dan pertarungan akan segera terlaksanakan dengan baik. Menguji dan mengasah kemampuan menjadi salah satu tujuan dalam permainan ini.

\section{Cara Kerja Alat}

Diperlukan sebuah alat untuk menjalankan inovasi ini. Alat ini dinamakan Pilih Jenis Tanaman sebagai edukasi media pembelajaran. Adapun komponen yang dibutuhkan adalah RFID, Arduino Uno, Kabel Jumper, Breadboard, I2C Serial, Card RFID, dan LCD. Langkah awal mencari sebuah program untuk melengkapi suatu alat. Selanjutnya merangkai komponen itu menjadi sebuah alat yang akan dapat dilihat di lampiran. Dalam proses kerjanya alat ini akan mendeteksi kartu yang sudah didaftarkan melalui program dan akan menampilkan jawaban jenis tanaman yang ditebak siswa sekolah dasar. LCD akan menampilkan hasil jawaban ketika RFID merespon kartu tersebut, dan fungsi dari arduino sebagai kontroller program yang dijalankan. Sila lihat Gambar 1.

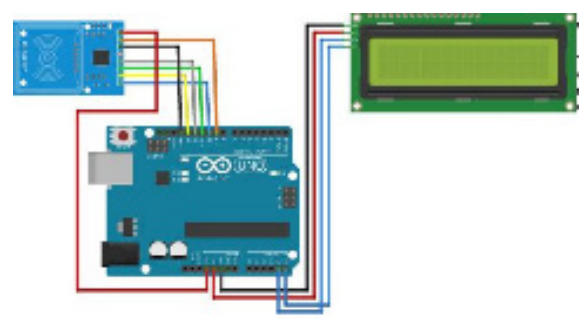

Gambar 1. Rangkaian elektronika Permainan Ular Tangga berbasis Arduino Uno dan RFID

\section{Komponen purwarupa}

Adapun komponen yang diperlukan untuk pembuatan purwarupa adalah sebagai berikut :

\section{Arduino UNO R3}

Arduino Uno R3 adalah merupakan sebuah mikrokontroller, dimana mikrokontroler tersebut akan memproses input yang diberikan melalui bahasa pemograman open source sehingga akan menghasilkan output. Cukup hubungkan Arduino dengan kabel USB ke PC atau Mac/Linux anda, jalankan software Arduino sudah bisa untuk memprogram chip ATmega328. Sila lihat Gambar 2.

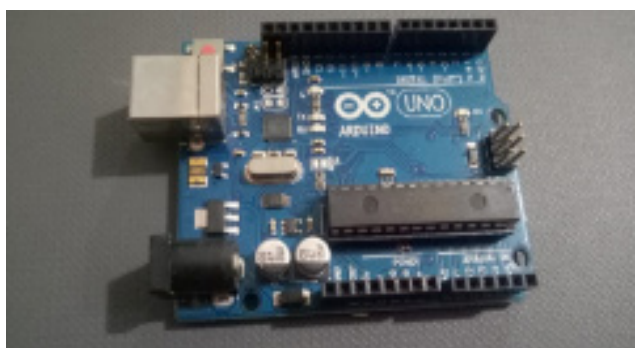

Gambar 2. Arduino Uno

\section{Breadboard}

Breadboard adalah dasar konstruksi sebuah sirkuit elektronik dan merupakan purwarupa dari suatu rangkaian elektronik. Breadboard banyak digunakan untuk merangkai komponen, karena dengan menggunakan breadboard, pembuatan purwarupa tidak memerlukan proses menyolder (langsung tancap ). Karena sifatnya yang solderless alias tidak memerlukan solder sehingga dapat digunakan kembali dan dengan demikian sangat cocok digunakan pada tahapan proses pembuatan purwarupa serta membantu dalam berkreasi dalam desain sirkuit elektronika., sila lihat Gambar 3.

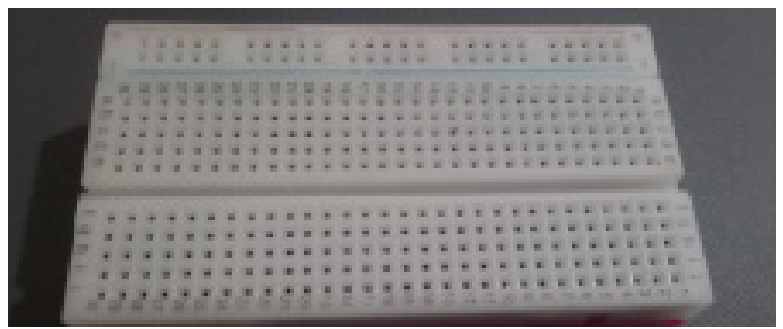

Gambar 3. BreadBoard

\section{Kabel jumper}

Kabel jumper adalah kabel yang di pergunakan untuk menghubungkan satu komponen dengan komponen lain ataupun menghubungkan jalur rangkaian yang terputus pada breadboard, sila lihat Gambar 4.

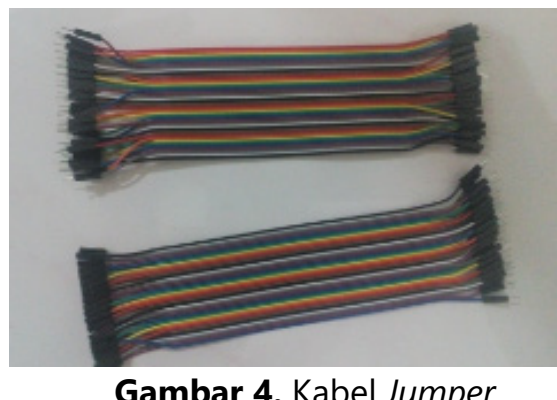

\section{Liquid Cristal Display (LCD)}

LCD adalah sebuah komponen elektronika yang dipergunakan untuk menampilkan tulisan, karakter dan huruf, LCD menggunakan kristal cair sebagai penampil utama. Dalam modul LCD terdapat mikrokontroller yang berfungsi sebagai pengendali tampilan karakter dilengkapi dengan memori dan register.Juga terdapat pin, yang salah satunya berfungsi untuk jalur untuk memberikan data karakter yang ingin ditampilkan Sila lihat Gambar 5.

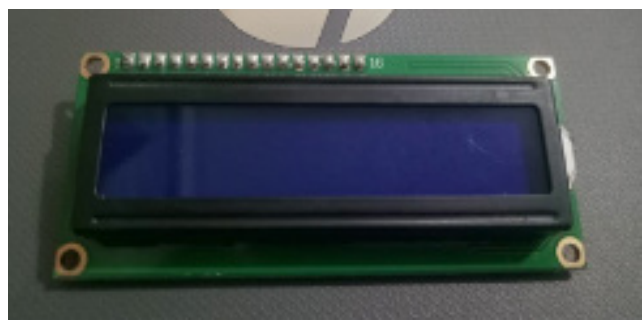

Gambar 5. Liquid Cristal Display 


\section{I2C Serial}

I2C Serial adalah modul LCD yang di kendalikan secara serial sinkron dengan protocol I2C (Inter Integratred Circuit). Penggunakan I2C Serial pada LCD dapat menghemat jumlah pin yang tersedia di dalam arduino dan membuat sketch pemrograman menjadi simple serta dapat menjaga LCD agar tidak cepat rusak. Sila lihat Gambar 6.

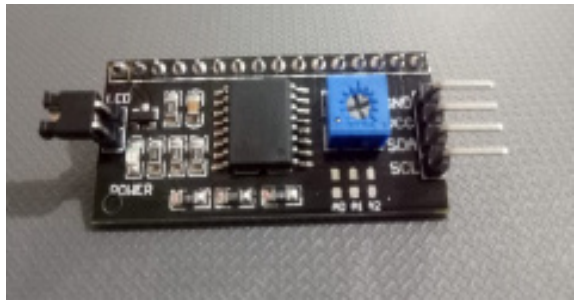

Gambar 6 . I2C Serial

\section{RFID}

RFID RC522 (Radio Frequency Identification) merupakan suatu teknologi yang memanfaatkan frekuensi radio sebagai pengidentifikasian terhadap suatu objek dengan menggunakan komponen elektronik melalui frekuensi radio dengan menggunakan piranti card tag. Card Tag RFID adalah sebuah perangkat yang akan diidentifikasi oleh RFID reader, dapat dapat berupa perangkat pasif maupun aktif yang berisi suatu data atau informasi. Perangkat pasif tidak menggunakan catudaya, sedangkan perangkat aktif wajib menggunakan. Sila lihat Gambar 7.

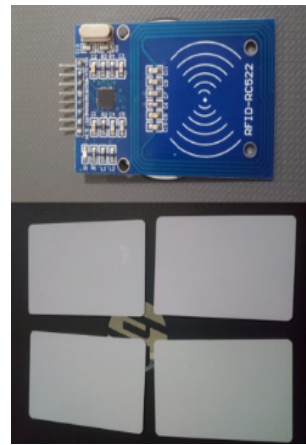

Gambar 7 RFID RC522 Reader dan Card Tag RFID Pasif

\section{PELAKSANAAN DAN METODE}

Peranan penting bagi ilmuwan pada abad ke-21 adalah berperan serta dalam mendidik masyarakat tentang metode dan hasil proses ilmiah (Kastner, and Knight, 2017), oleh sebab itu diperlukan proses desain rekayasa untuk mampu menghasilkan inovasi berbasiskan teknologi yang semakin berkembang dan memiliki fungsi yang tepat dan mudah untuk digunakan. Jika di masa lalu desainer dievaluasi hanya berdasarkan pada keterampilan teknis mereka, di masa depan akan lebih banyak lagi kebutuhan untuk desainer yang bersedia bekerja dengan pendekatan yang lebih sistemik dan strategis dalam skala yang lebih besar (Irbite, and
Strode, 2016). Proses Desain Rekayasa adalah merupakan sebuah proses didalam mendesain dengan berpusat kepada pengguna. dimulai dengan etnografi hingga menghasilkan sebuah purwarupa yang merupakan sebuah konsep solusi yang sesuai dengan kebutuhan di masyarakat.

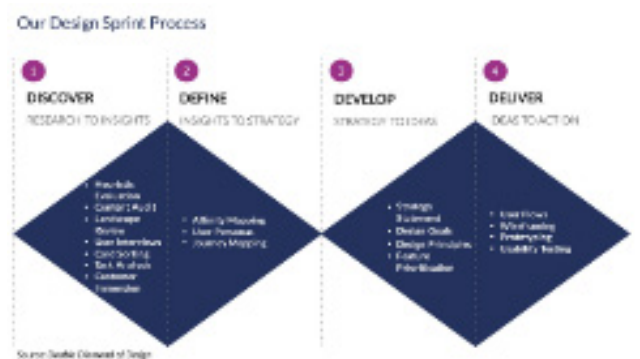

Gambar 8. Tahapan pada Proses Desain Rekayasa

Proses ini memiliki 4 tahapan, pada tahapan awal dimulai dengan observasi secara luas di masyarakat untuk mendapatkan permasalahan-permasalahan, tahapan kedua adalah proses pengerucutan dengan melakukan pemilihan permasalahan utama, tahapan ketiga adalah mengembangkan ideide sebagai solusi terhadap permasalahan utama dan tahapan terahir adalah menetukan solusi utama untuk dapat dilanjutkan ke tahapan pembuatan purwarupa dan pengujian terhadap pengguna, sila lihat Gambar 8. Dalam tahapan pengujian terhadap pengguna akan terdapat proses iterasi untuk mendapatkan masukan untuk perbaikan inovasi nantinya.

\section{Proses Etnografi}

Desainer menggunakan metode observasi kualitatif dengan pendekatan secara sosial etnografi yang dengannya mereka dapat mempelajari orang secara mendalam, memahami bagaimana mereka melakukan kegiatan mereka dan faktor lingkungan yang ikut berperan. Metode ini sangat memakan waktu, sehingga didalam penelitian ini hanya memeriksa sejumlah kecil orang.

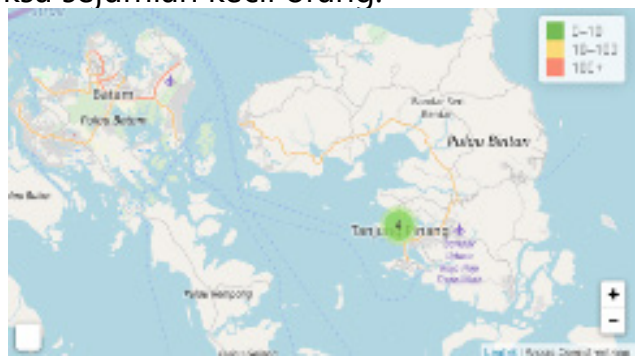

Gambar 9. Lokasi SDN 003 Binaan Tanjung pinang [9]

(http://sekolah.data.kemdikbud.go.id)

Adapun metode observasi yang dipergunakan adalah metode observasi peneliti sebagai peserta (observer as participant), yaitu kelompok yang sedang diteliti mengetahui tentang keberadaan peneliti, namun peneliti tidak ikut serta melakukan kegiatan dan aktifitas didalam kelompok 
yang sedang diteliti. Lokasi penelitian dilakukan di SDN003 Binaan Tanjung pinang, Kepulauan Riau, sila lihat Gambar 9.

Langkah awal dari Proses Desain Rekayasa, yang merupakan aktivitas pegamatan atau observasi secara langsung ke masyarakat di suatu daerah untuk mendapatkan data yang akurat sehingga mampu menghasilkan sebuah solusi yang tepat. Pada Gambar 10 menampilkan keadaaan di SDN 003 Binaan Tanjung pinang untuk mendapatkan data-data yang di perlukan.
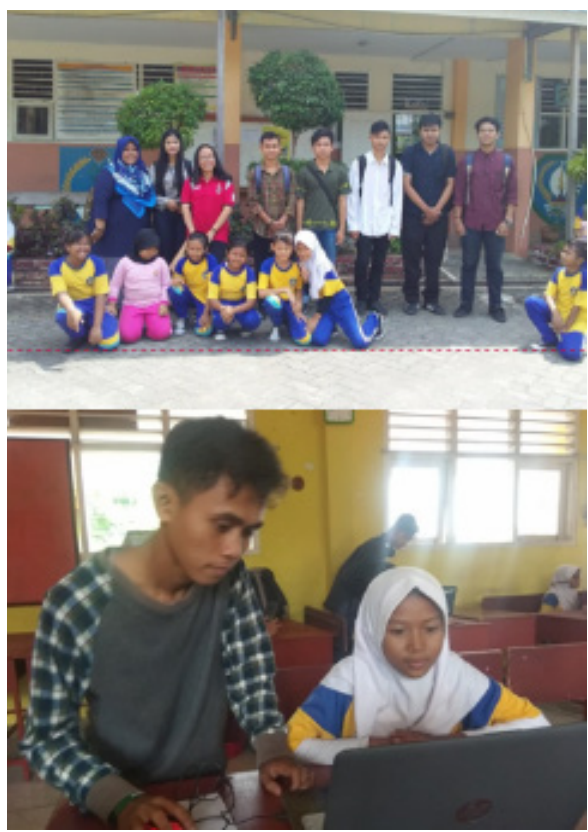

Gambar 10. Suasana di SDN 003 Binaan Tanjung pinang

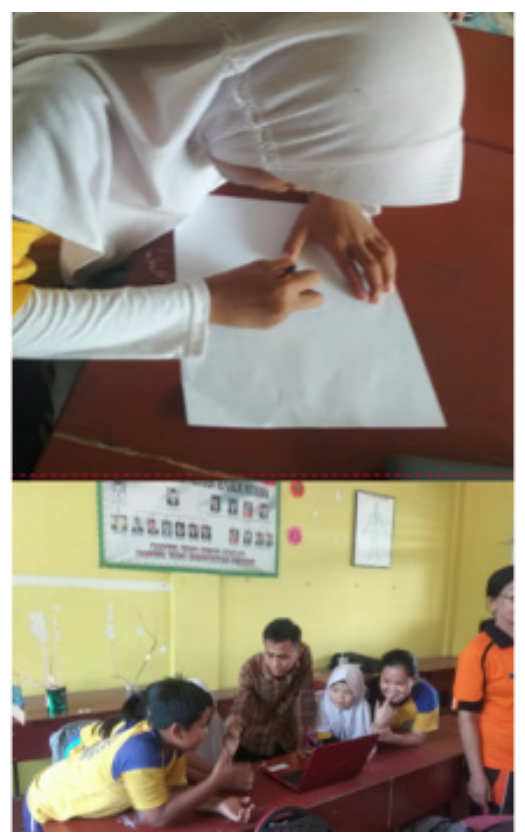

Gambar 11. Mengumpulkan informasi permasalahan.
Metode etnografi yang diterapkan pada penelitian ini adalah peneliti sebagai peserta, dimana kelompok yang sedang diteliti mengetahui tentang keberadaan peneliti, namun peneliti tidak ikut serta melakukan kegiatan dan aktifitas didalam kelompok yang sedang diteliti (Wagner, Kawulich, and Garner, 2012). Pada Gambar 11 memperlihatkan peneliti melakukan proses pengumpulan informasi di SDN 003 BinaanTanjung pinang melalui siswa.

\section{Proses pengumpulan masalah yang terdapat di sekolah dan menentukan permasalahan utama}

Tahapan selanjutnya adalah curahan gagasan permasalahan yang ditemukan di sekolah dari hasil observasi, dimana semua permasalahan yang ditemukan akan di dokumentasikan. Proses ini adalah merupakan tahapan yang penting, karena sangat diharapkan bahwa solusi yang akan dihasilkan adalah merupakan solusi yang dibutuhkan, bukan solusi yang diminta oleh calon pengguna. Pola penyampaian gagasan secara bebas akan sangat diperlukan untuk memotivasi peneliti untuk mampu berpikir inovatif dan kreatif. Curahan gagasan yang bersifat luas adalah merupakan pondasi bagi rekayasawan untuk mampu menghasilkan sebuah inovasi yang berbasiskan teknologi. Hal ini sering dipahami dengan T concept, dimaksudkan bahwa inovasi yang dihasilkan memiliki pengaruh yang luas dan mendalam. Pada Gambar 12 dapat dilihat hasil dari proses pengumpulan masalah-masalah yang sangat berkaitan dengan kejadian di sekolah selama melakukan observasi dan wawancara

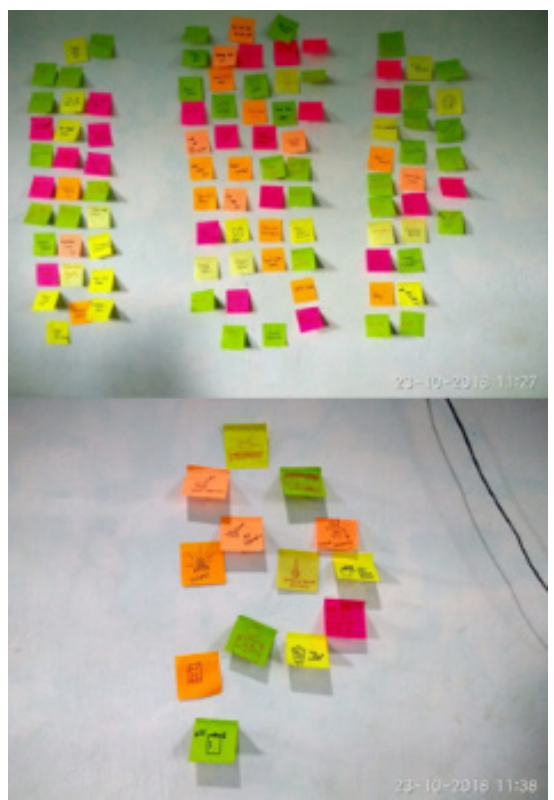

Gambar 12. Proses pengumpulan masalah

Permasalahan utama adalah satu permasalahan yang akan dijadikan landasan untuk langkah penentuan solusi, dalam tahapan ini akan dilakukan proses pengerucutan masalah, dimulai dengan 
pengelompokan masalah dan selanjutnya di pilih satu masalah saja, lihat Gambar 13

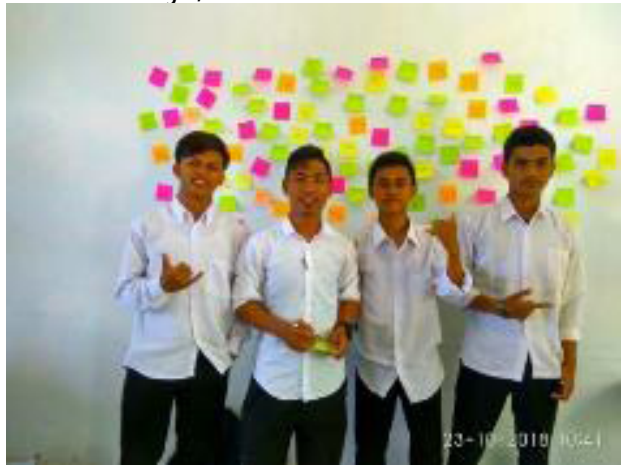

Gambar 13. Proses pengerucutan masalah untuk mendapatkan masalah utama

Proses diskusi bersama sesama anggota kelompok dengan saling memberikan penjelasan terhadap masalah yang akan dijadikan masalah utama diperlukan untuk mendapatkan informasi-informasi yang belum dapat disampaikan pada tahapan sebelumnya. Adapun permasalahan utama dari penelitian ini adalah Pengetahuan jenis tanaman.

\section{ANALISA DAN PEMBAHASAN Purwarupa}

Tahapan yang sudah mulai memerlukan pembiayaan adalah tahapan pembuatan purwarupa. Oleh sebab itu pada Proses Desain Rekayasa ini, menekankan untuk mampu menghasilkan purwarupa sederhana yang ekonomis dan fleksible, dengan maksud bahwa perubahan rancangan dapat dilakukan dengan mudah dan tidak akan memerlukan pembiayaan yang besar. Purwarupa dalam tahapan ini lebih dikenal dengan istilah low resolution prototype (Nusyirwan, 2017). Sedangkan pada Gambar 14 adalah sebuah purwarupa sederhana dari permainan ular tangga mempergunaka Arduino uno dan rfid

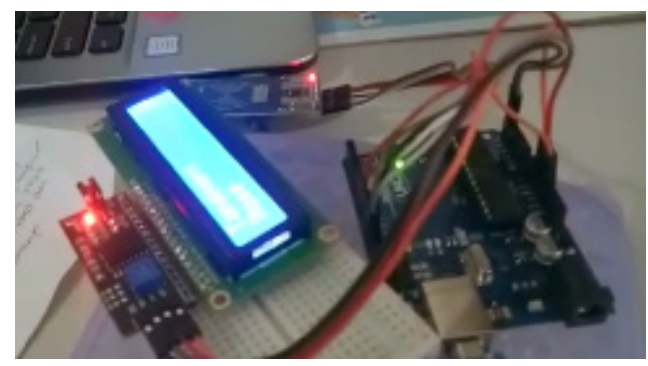

Gambar 14. Purwarupa Sederhana

\section{Pengujian Kegunaan}

Pengujian kegunaan adalah proses evaluasi terhadap inovasi yang dirancang dengan berbasis pengguna. Pada tahapan ini pengguna akan berpartisipasi dan berinteraksi secara langsung dengan purwarupa sederhana yang dihasilkan dari proses sebelumnya. Pengguna akan diminta untuk melakukan tugas tertentu atau hanya menjelajahinya secara bebas, sementara perilaku pengguna diamati dan dicatat untuk mengidentifikasi kelemahan desain yang menyebabkan kesalahan atau kesulitan pengguna. Selama pengamatan ini, Setelah kelemahan desain telah diidentifikasi, rekomendasi desain diusulkan untuk meningkatkan kualitas ergonomis produk (Bastien, 2010) Pada Gambar 15 menampilkan pengujian kegunaan purwarupa.

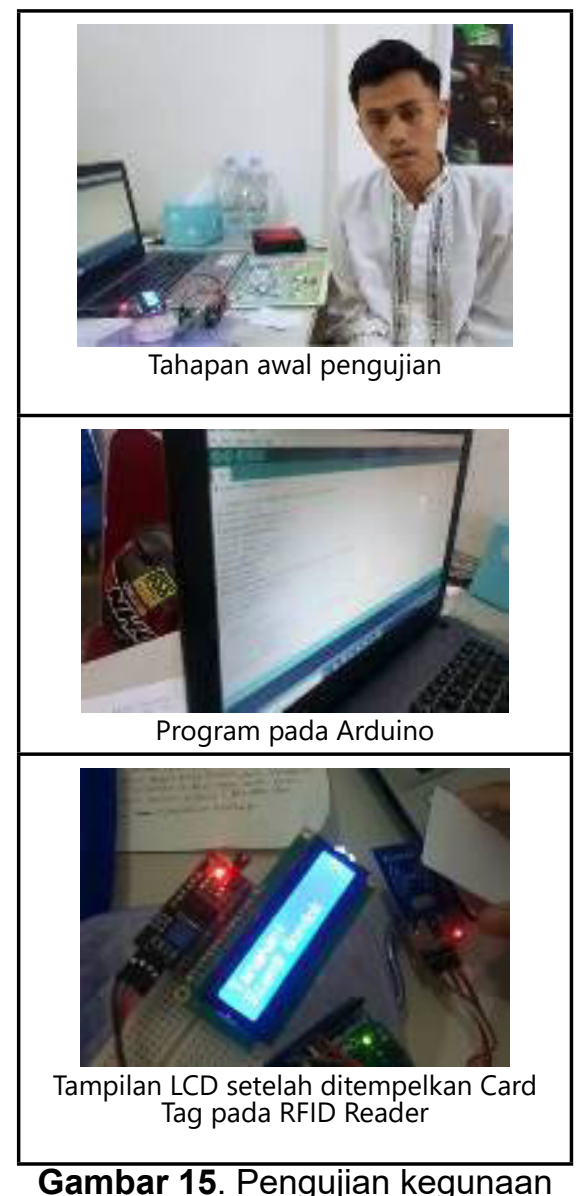

Pengalaman pengguna akan memperluas pandangan tentang interaksi produk dengan pengguna dari aspek emosional. Adapun motivasi dari proses pengalaman pengguna adalah untuk mengembangkan pengalaman dan emosi positif. Oleh karena itu, produk harus memenuhi kebutuhan psikologis dan motif pelanggan (von Saucken, Lachner, and Lindemann, (2014). Pada Gambar 16 menampilkan pengujian pengalaman kepada siswa calon pengguna. 


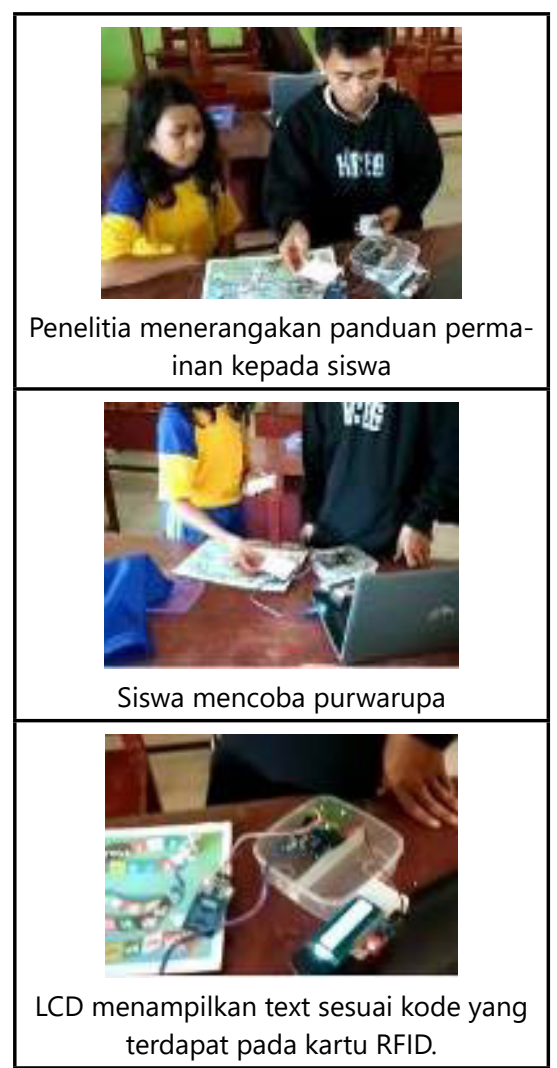

Gambar 16. Pengujian pengalaman siswa calon pengguna

Inovator yang berbasiskan teknologi sangat sadar bahwa kesuksesan hasil inovasi tidak hanya dilihat dari manfaat dari produk yang akan dihasilkan namun juga perlu memperhatikan faktor pengalaman pengguna., sehingga pengembangan inovasi teknologi tidak lagi hanya tentang mengimplementasikan fitur dan menguji kegunaannya, tetapi juga tentang mendesain produk yang menyenangkan dan mendukung kebutuhan dan nilai-nilai dasar manusia. Dengan demikian, pengalaman pengguna dalam tahapan Proses Desain Rekayasa harus menjadi perhatian utama pengembangan produk (Johnson, Clegg, and Ravden, 1989), sila lihat pada Tabel 1 dan Tabel 2.

\section{Program pada Arduino}

Dibawah ini adalah program yang ditulis pada Arduino untuk dapat menghasilkan luaran sesuai yang di inginkan pada Permainan ular tangga berbasis ardunio uno dan rfid guna mengembangkan ilmu pengetahuan anak sekolah dasar dalam mengenal jenis tanaman.

Pada Gambar 17 menjelaskan bahwa purwarupa ini memiliki komponen LCD 16x2 lengkap dengan serial interface I2C dan module RFID sebagai komponen utama. Jika menggunakan I2C maka harus mengetahui dulu alamat $\mathrm{I} 2 \mathrm{C}$ dari serial interface tersebut. Setelah memasukan library LCD 16x2 dengan I2C maka kita lanjut memasukan library dari module RFID agar dapat melakukan pembacaan card tag pada RFID.
Tabel 1. Hasil Interview dari calon pengguna pertama

\begin{tabular}{|c|c|c|c|c|c|c|}
\hline & & 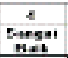 & $\begin{array}{l}\bar{a} \\
\text { Buik }\end{array}$ & $\begin{array}{c}2 \\
\text { cubos }\end{array}$ & \begin{tabular}{|c|}
1 \\
Kenare
\end{tabular} & 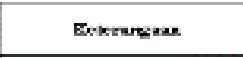 \\
\hline 1 & 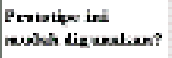 & & & & & 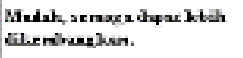 \\
\hline$=$ & 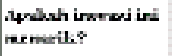 & & & & & Saicst infroutk. \\
\hline ד. & 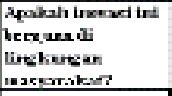 & & & & & 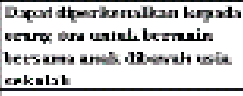 \\
\hline 1 & 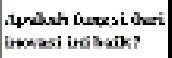 & & & & & 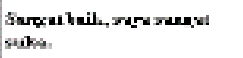 \\
\hline$a$ & 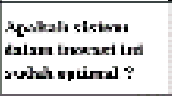 & & & & & 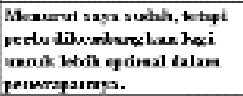 \\
\hline
\end{tabular}

Tabel 2. Hasil Interview dari calon pengguna pertama
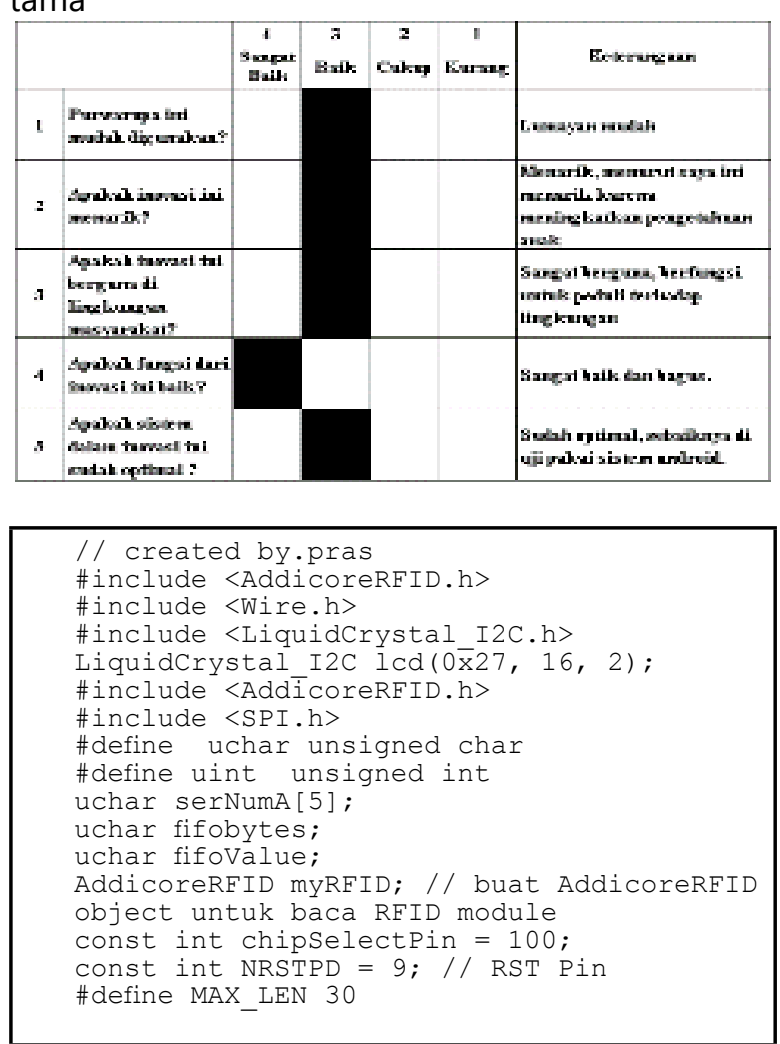

Gambar 17. Inisialisasi dan memasukan library komponen.

Sedangkan pada Gambar 18. menjelasakan serial komunikasi yang digunakan pada purwarupa ini yang akan di tampilkan di serial monitor 9600 baud, Di dalam void setup ini RFID menjadi output. Jika kita menggunakan LCD 16×2 untuk menampilkan text monitor kita harus set posisi baris nya, pada program ini posisi set cursor nya di 3,0 dan 2,1 dengan delay 5 detik. RFID di set pada saat card tag di tempelkan maka LCD 16×2 akan menampilkan text monitor " pinang lestari". 
void setup ()

\{

Serial.begin (9600);

SPI.begin () ;

pinMode (chipselectPin, OUTPUT) ;

digitalWrite (chipselectPin, LOW) ;

pinMode (NRSTPD, OUTPUT)

digitalWrite (NRSTPD, HIGH);

myRFID.AddicoreRFID Init() ;

lcd.begin ();

for (int $i=0 ; i<3 ; i++)$

\{

lcd.backlight ();

delay (500);

lcd. setCursor $(3,0)$;

lcd.print ("Pinang ");

lcd. setCursor $(2,1)$;

lcd.print (" Lestari ");

lcd.noBacklight ();

delay (500);

lcd.backlight () :

\}

delay (500);

lcd.clear ();

$1 \mathrm{~cd}$. setCursor $(2,0)$;

lcd.print ("TEMPEL KARTU");

Gambar 18. Void setup untuk mengatur input dan output komponen yang digunakan.

void loop ()

\{

Serial.println("RFID tag

detected")

Serial.print (str[0],BIN);

Serial.print (", ");

Serial.print (str[1],BIN);

Serial.println(" ");

\}

if $(\operatorname{str}[0]==205)$

// atur menggunakan nomor awal kartu RFID

lcd.clear ();

lcd. $\operatorname{set}$ Cursor $(0,0)$;

lcd.print ("Treseme:");

delay (500):

lcd. setCursor $(0,1)$;

lcd.print ("B01 (Kode)");

Gambar 19. Void loop fungsi perulangan sketch program.

Dapat dilihat pada Gambar 19, dimana masingmasing card tag RFID telah di beri nama dan pada saat di tempelkan di module maka LCD 16x2 akan menampilkan text monitor sesuai dengan nama card tag yang udah di atur, sebagai contoh card tag RFID 205 yang sebelumnya sudah di daftarkan pada saat di tempelkan di module maka LCD akan menampilkan text monitor "Tresme" .

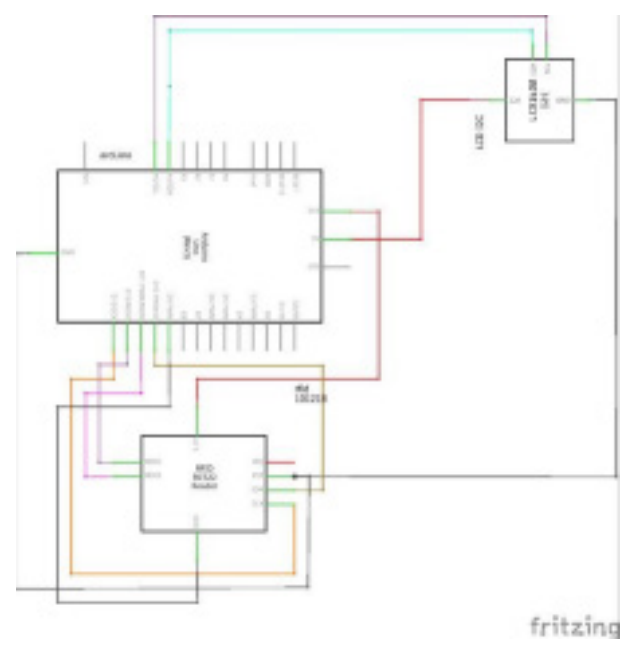

Gambar 20. Diagram alir purwarupa

Adapun komponen yang diperlukan untuk pembuatan purwarupa dengan estimasi harga adalah sila lihat pada Tabel 3.

Tabel 3. Estimasi anggaran (Fabric Technology Surabaya/ Bukalapak, diakses 28 Mei 2019)

\begin{tabular}{|c|c|c|c|c|}
\hline No. & Barang & $\frac{\frac{\pi}{\pi}}{\frac{\pi}{3}}$ & $\frac{\sqrt[\pi]{\frac{\pi}{\pi}}}{\frac{\pi}{x}}$ & 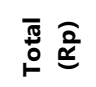 \\
\hline 1 & ARDUINO UNO & 1 & 85000 & 85000 \\
\hline 2 & $\begin{array}{l}\text { MFRC-522 (RFID) } \\
\text { dan RFID Tag }\end{array}$ & 1 & 45000 & 45000 \\
\hline 3 & LCD 1602 & 1 & 25000 & 25000 \\
\hline 4 & I2C 1602 & 1 & 11000 & 11000 \\
\hline 5 & JUMPER MALE TO MALE & 1 & 16000 & 16000 \\
\hline 6 & JUMPER FAMALE TO MALE & 1 & 16000 & 16000 \\
\hline 7 & BREADBOARD & 1 & 11000 & 11000 \\
\hline & Jumlah & & & 209.000 \\
\hline
\end{tabular}

\section{KESIMPULAN DAN SARAN}

Permainan ular tangga dapat menjadi salah satu permainan Edukasi yang menerapkan jenis tanaman sebagai ilmu pengetahuan anak sekolah dasar. Sebagai metode lanjutan ilmu pengetahuan yang memperkuat inovasi Pilih Jenis Tanaman untuk menciptakan sebuah keunggulan, dan buku panduan sebagai pengantar tata cara main dalam inovasi.

Perlunya pengembangan dari inovasi ini untuk dapat dikembangkan. Inovasi ini dapat diterapkan karena mudah dan efisien. Selanjutnya bertujuan mendambah ilmu pengetahuan masyarakat pesisir tekhusus anak sekolah dasar.

\section{DAFTAR PUSTAKA}

Bastien, J., M., C., (2010). Usability testing: a review of some methodological and technical aspects of the method", International Journal of Medical Informatics, Vol. 79, No. 4, pp e18-e23, Elsevier Ireland Ltd. 
96 | Nusyirwan, D. dkk. Permainan Ular Tangga Berbasis Arduino Uno dan RFID...

Gunanto ,S., G., (2016), Penciptaan Permainan Digital Edukatif Berbasis Wawasan Budaya Dan Pendidikan Karakter, Journal of Animation and Games Studies, Vol. 2, No.2, pp 207228.

Irbīte, A., and Strode, A., (2016). Design Thinking Models In Design Research And Education, Proceedings of the International Scientific Conference. Vol. IV, pp 488-500

Janar, M., Sutopo, W., dan Yurianistanto, (2015), Perkembangan Model Game Theory Pada Skema Persedian Penyangga Untuk Menjamin Ketersediaan Dan Kestabilan Harga Komoditas Gula Pasir, Jurnal Teknik Industri, Universitas Diponegoro, Vol. X, No. 2, pp 97 $-102$.

Johnson, G., I., Clegg, C., W., and Ravden, S., J., (1989). Towards Practical User Experience Evaluation Methods, Journal Applied Ergonomics, Volume 20, No. 4, pp 255-260, Elsevier Ltd

Jordi, D., (2017). Perancangan Board Game Edukatif Tentang Peduli Lingkungan Untuk Anak Usia 7-12 tahun, Tugas Ahir S1. Universitas Negeri Padang

Kastner, S., and Knight, R., T., (2017). Bringing Kids Into The Scientific Review Process. Neuron Vol. 93, Edisi 1, pp 12-14, Elsevier Inc
Kilicaun,M., Y., (2014). The Games 3-6 Aged Children's Wish To Play In The School Garden. Procedia - Social and Behavioral Sciences 152, Elsevier Ltf, pp $233-240$

Wagner, C., Kawulich, B., \& Garner, M., (2012). Collecting Data Through Observation, Doing Social Research: A global context, McGraw Hill

Nusyirwan, D., (2017). Engineering Design Process Engineering Student Centered Experience Learning (ESCEL) di Jurusan Teknik Elektro Universitas Maritim Raja Ali Haji (UMRAH). Jurnal Sustainable, Universitas Maritim Raja Ali Hajj, Vol. 06, No. 01, pp. 24-35

von Saucken, C., Lachner, F., and Lindemann,U., (2014). Principles for User Experience What We Can Learn from Bad Examples, International Conference on Kansei Engineering \& Emotion Research.

Wijaya, E., (2013). Perancangan Permainan Greenplay Sebagai Sarana Pembelajaran Peduli Lingkungan Bagi Anak-Anak, Jurnal Calyptra, Universitas Surabaya, Vol.2, No.2.pp 1-18

iChangi App Redesign [Daring], Tersedia pada : https://www.anna-chung.com/ichangi-app [ Diakses : 31 Mei 2019].

Sekolah Kita [Daring], Tersedia pada : http:// sekolah.data.kemdikbud.go.id/index.php/ chome/profil/90AD19BD-31F5-E011-B7F83B12490BB869 [ Diakses : 31 Mei 2019 ]. 